\title{
Simulasi Aliran Plasma dengan Variasi Kecepatan Injeksi Plasma pada Potensial Penghalang dalam Posisi Melayang
}

\author{
Muliady Faisal $^{* 1}$, Acep Purqon ${ }^{2}$ \\ ${ }^{1}$ Magister Sains Komputasi, FMIPA ITB, ${ }^{2}$ Fisika Bumi dan Sistem Kompleks FMIPA ITB \\ ${ }^{* 1}$ muliadyfaisalalmandary@gmail.com, ${ }^{2}$ acep@fi.itb.ac.id
}

\begin{abstract}
Abstrak
Dalam penelitian ini akan diperlihatkan bentuk difusi aliran plasma yang terjadi akibat variasi kecepatan injeksi plasma pada sebuah potensial penghalang dalam posisi melayang pada kasus distribusi kerapatan muatan dan daerah potensial listrik yang diturunkan dari persamaan Poisson. Metode yang digunakan dalam penelitian ini adalah Particle-In-Cell (PIC). Dalam metode PIC, elektron dan proton merupakan sumber dari plasma. Secara numerik step waktu yang digunakan dalam penelitian yaitu setiap 1 detik dengan periode plasma selama 200 detik dan grid yang digunakan yaitu $20 \times 20$. Adapun potensial penghalangnya berbentuk persegi. Dari variasi kecepatan injeksi berpengaruh terhadap kerapatan muatan sehingga jika kecepatan injeksinya diperbesar maka akan terdapat daerah kosong yang tidak terisi dibelakang potensial penghalang. Sedangkan untuk daerah potensial listrik jika kecepatan injeksi plasmanya diperbesar maka daerah dibelakang potensial penghalang akan terdapat daerah yang berpotensial yang lebih kecil.
\end{abstract}

Kata kunci: Plasma, PIC, Potensial penghalang

\section{PENDAHULUAN}

Sebuah plasma dapat dibuat dengan memanaskan gas atau mengalirkannya ke medan elektromagnetik yang kuat, diterapkan dengan laser atau microwave pembangkit. Hal ini mengurangi atau meningkatkan jumlah elektron, menciptakan partikel bermuatan positif atau negatif yang disebut ion, Merlino R.L (1998) dan disertai oleh disosiasi ikatan molekul Sturrock dan Peter A (1994)

Kehadiran jumlah signifikan dari partikel bermuatan membuat plasma elektrik konduktif sehingga merespon kuat medan elektromagnetik. Seperti gas, plasma tidak memiliki bentuk yang pasti atau volume yang pasti kecuali tertutup dalam sebuah wadah. Tidak seperti gas, di bawah pengaruh medan magnet, itu dapat membentuk struktur seperti filamen, balok dan lapisan ganda.

Ketika plasma atau partikel bermuatan bergerak menghasilkan arus listrik dan medan magnet. Tiga faktor yang mempengaruhi aliran plasma. Pertama, approksimasi plasma: partikel bermuatan yang dekat saling berpengaruh. Apporksimasi plasma valid ketika sejumlah partikel bermuatan berada dalam lingkup interaksi. Hal ini disebut Panjang Debye $\lambda$. Kedua, interaksi bulk: Panjang Debye lebih pendek daripada fisik plasma. Ketiga, 
frekuensi plasma: frekuensi elektron plasma terjadi akibat adanya tumbukan dengan partikel proton.

Plasma adalah bentuk paling berlimpah dialam semesta, buktinya dapat ditemukan didaerah inter galaksi, terutama di daerah intercluster dan bintang termasuk matahari. Bentuk umum plasma di bumi diproduksi di lampu-lampu neon. Pengolahan teknologi plasma telah dikembangkan secara intensif selama lebih dari tiga dekade dan telah membuat kemajuan luar biasa dan sukses sebagai teknologi manufaktur kunci untuk berbagai aplikasi industri dalam H. Conrads dan M. Schmidt (2000) Mulai dari modifikasi permukaan bahan untuk teknologi perangkat-manufaktur maju dan proses biomaterial. teknologi plasma pengolahan ini telah didasarkan pada generasi dan kontrol spesies reaktif (radial dan ion) dalam plasma tekanan rendah berkelanjutan dalam ruang hampa. Karena tabrakan cukup antara elektron dan molekul gas dalam plasma tekanan rendah ini dalam A. Schutze, dkk (1998). Suhu gas dijaga biasanya pada suhu kurang dari suhu elektron dari beberapa elektron volt. Terlepas dari keberhasilan pengembangan plasma tekanan rendah sebagai kunci teknologi manufaktur kunci, plasma tekanan rendah memiliki beberapa kelemahan; sistem vakum diperlukan untuk generasi plasma pada tekanan gas berkurang dan dengan demikian plasma tekanan rendah tidak dapat diterapkan secara langsung untuk diproses atau perawatan jaringan biomedis dengan fase cair. Plasma generasi baru pada tekanan atmosfer dapat mengatasi kelemahan dari plasma tekanan rendah . Mempertahankan plasma tekanan atmosfer, bagaimanapun, memerlukan tegangan tinggi untuk gangguan gas dan cenderung menunjukkan busur dan gas pemanas karena ditingkatkan tabrakan antara elektron dan molekul gas dalam A. Schutze, dkk (1998). Untuk menghindari busur dan menurunkan suhu gas di atmosfer bertekanan plasma untuk mencapai sumber - suhu rendah ,beberapa skema memiliki dikembangkan melalui konfigurasi elektroda benar merancang dan bentuk gelombang tegangan discharge eksitasi untuk membatasi durasi debit dalam C Tendero (2006).

\section{METODE PANENELITIAN}

\subsection{Simulasi Plasma}

Fenomena aliran plasma merupakan hal yang menarik untuk diamati baik secara eksperimen maupun simulasi. Dalam penelitian ini akan diperlihatkan bentuk difusi aliran plasma yang terjadi akibat variasi kecepatan injeksi plasma pada sebuah potensial penghalang dalam posisi melayang pada kasus distribusi kerapatan muatan dan daerah potensial listrik yang diturunkan dari persamaan Poisson. Metode yang digunakan dalam penelitian ini adalah Particle-In-Cell (PIC). Dalam metode PIC, elektron dan proton merupakan sumber dari plasma.

\subsection{Persamaan Fundamental}

Metode yang digunakan bersumber dari blog Particle-In-Cell (PIC) Consulting yaitu : The Electrostatis Particle-In-Cell (ES-PIC) Metohd dan Simple Particle-In-Cell Code In Matlab. Nilai kerapatan muatan adalah jumlah banyaknya partikel bermuatan dalam dimensi ruang. Untuk mencari nilai kerapatan muatan digunakan rumus: 


$$
\rho=e\left(Z_{p} n_{p}-n_{e}\right)
$$

Keterangan:

$$
\begin{aligned}
& \rho=\text { kerapatan muatan } \\
& \mathrm{e}=\text { elektron } \\
& \mathrm{Z}_{\mathrm{p}}=\text { jumlah rata-rata proton } \\
& \mathrm{n}=\text { jumlah proton } \\
& \mathrm{n}_{\mathrm{e}}=\text { jumlah elektron. }
\end{aligned}
$$

Sedangkan untuk mencari daerah potensial listriknya, pertama-tama menggunakan Hukum kedua Newton

$$
\begin{gathered}
\vec{a}=\frac{\vec{F}}{m} \\
\frac{d \vec{v}}{d t}=\frac{q}{m} \vec{E}
\end{gathered}
$$

Keterangan:

$$
\begin{aligned}
& \mathrm{a}=\text { percepatan } \\
& \mathrm{F}=\text { gaya } \\
& \mathrm{q}=\text { muatan partikel } \\
& \mathrm{m}=\text { massa partikel } \\
& \mathrm{E}=\text { medan elektrostatis }
\end{aligned}
$$

Medan elektrostatis dapat dinyatakan dalam gradient potensial listrik

Berdasarkan Persamaan Poisson

$$
\vec{E}=-\nabla \phi
$$

$$
\nabla^{2} \phi=-\frac{\rho}{\varepsilon_{0}}
$$

Sehingga potensial listriknya dapat dicari.

dimana:

$\phi=$ Potensial listrik

$\varepsilon_{0}=$ Permitivisitas ruang bebas

\subsection{Persamaan yang digunakan dalam simulasi}

Persamaan yang digunakan dalam penelitian ini adalah rumus menghitung nilai kerapatan muatan dan potensial listrik. Terkhusus potensial listrik persamaanya didiskrititasi.

\section{Kerapatan muatan}

Potensial Listrik

$$
\rho=e\left(Z_{p} n_{p}-n_{e}\right)
$$

$$
\frac{\phi_{i-1, j}-2 \phi_{i, j}+\phi_{i+1, j}}{\Delta^{2} x}+\frac{\phi_{i, j-1}-2 \phi_{i, j}+\phi_{i, j+1}}{\Delta^{2} y}=-\frac{\epsilon}{\varepsilon_{0}}\left(n_{p}-n_{e} \exp \left(\frac{\phi_{i}-\phi_{0}}{k T_{e}}\right)\right)
$$




\section{Diagram alir penelitian}

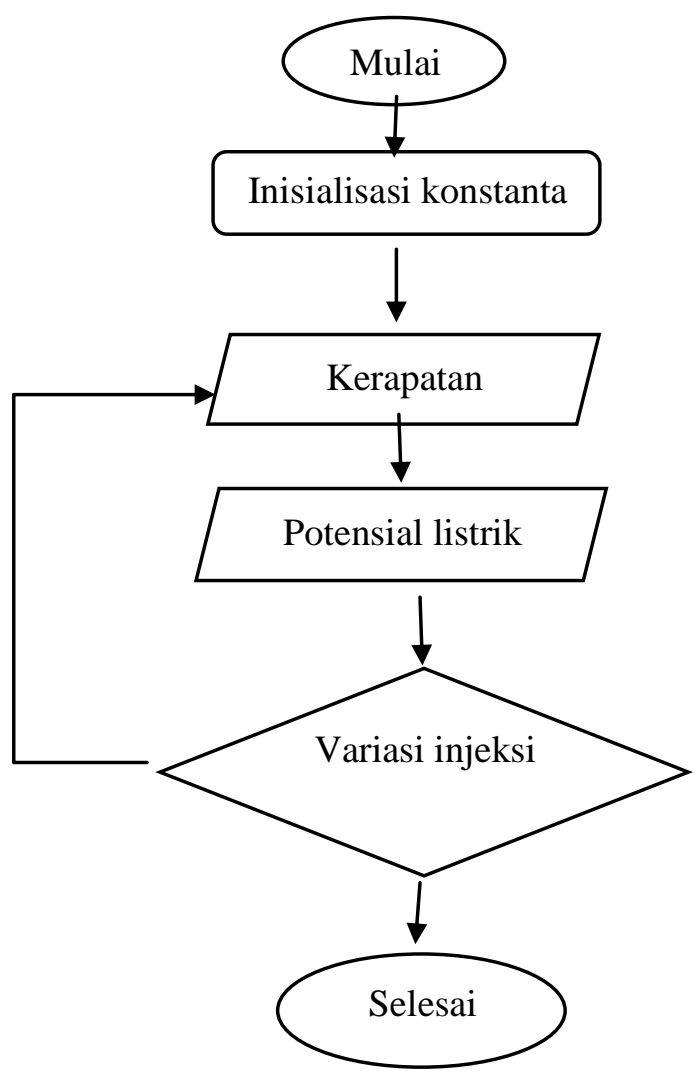

Konstanta yang digunakan dalam simulasi ini, akan diperlihatkan pada tabel berikut :

Tabel 1 Parameter konstanta yang digunakan dalam simulasi

\begin{tabular}{|l|l|}
\hline $\begin{array}{l}\text { Parameter } \\
\text { konstanta }\end{array}$ & Keterangan \\
\hline $\mathrm{n}_{0}$ & Kerapatan muatan pada $/ \mathrm{m}^{3}$ \\
\hline $\mathrm{T}_{\mathrm{e}}$ & Temperatur elektron pada $1 \mathrm{eV}$ \\
\hline $\mathrm{T}_{\mathrm{p}}$ & Temperatur proton pada $0.1 \mathrm{eV}$ \\
\hline$\phi_{0}$ & Potensial penghalang awal $=0$ \\
\hline$\phi_{p}$ & Bidang potensial penghalang $=-5$ \\
\hline
\end{tabular}


Tabel 2 Ukuran dimensi bidang dan step waktu serta variasi injeksi kecepatan yang digunakan dalam simulasi

\begin{tabular}{|l|l|}
\hline Parameter & Keterangan \\
\hline $\mathrm{nx}$ & Jarak kurva dalam sumbu $\mathrm{x}=20$ \\
\hline $\mathrm{ny}$ & Jarak kurva dalam sumbu $\mathrm{y}=20$ \\
\hline $\mathrm{ts}$ & Periode injeksi plasma $=200$ detik \\
\hline $\mathrm{dt}$ & $\begin{array}{l}\text { Step waktu yang digunakan untuk mengamati difusi } \\
\text { plasma }=1 \text { detik }\end{array}$ \\
\hline $\begin{array}{l}\text { Variasi } \\
\text { kecepatan }\end{array}$ & $5 \mathrm{~km} /$ detik sampai $50 \mathrm{~km} /$ detik \\
\hline
\end{tabular}

\section{HASIL DAN PEMBAHASAN}

Simulasi dilakukan dengan menggunakan software matlab R2010b. Hasil penelitian ini diperlihatkan pada gambar berikut ini:
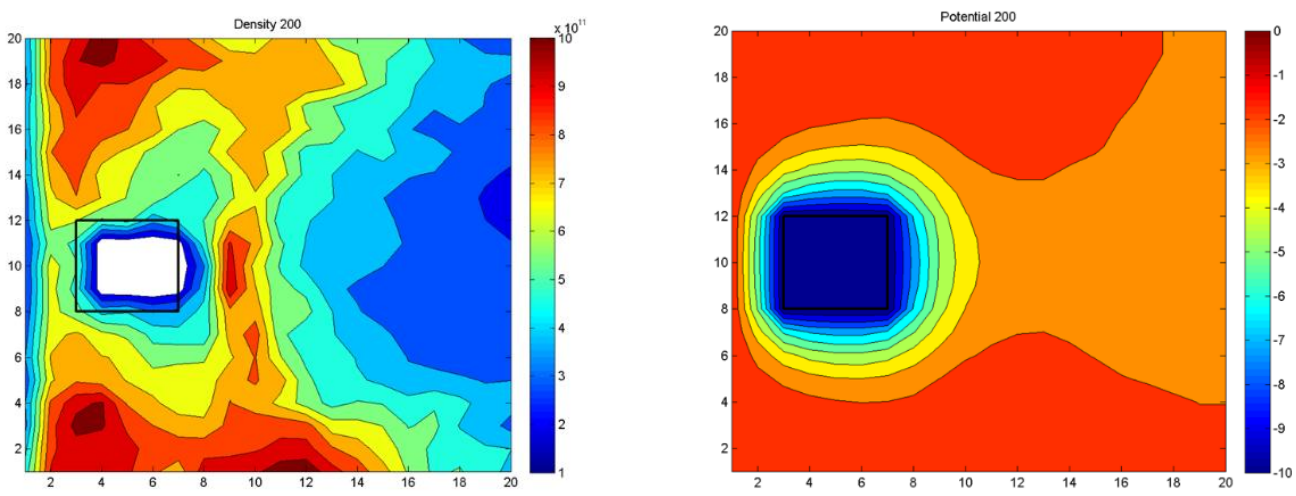

Gambar 1: Variasi injeksi plasma pada kecepatan $5 \mathrm{~km} / \mathrm{detik}$ 

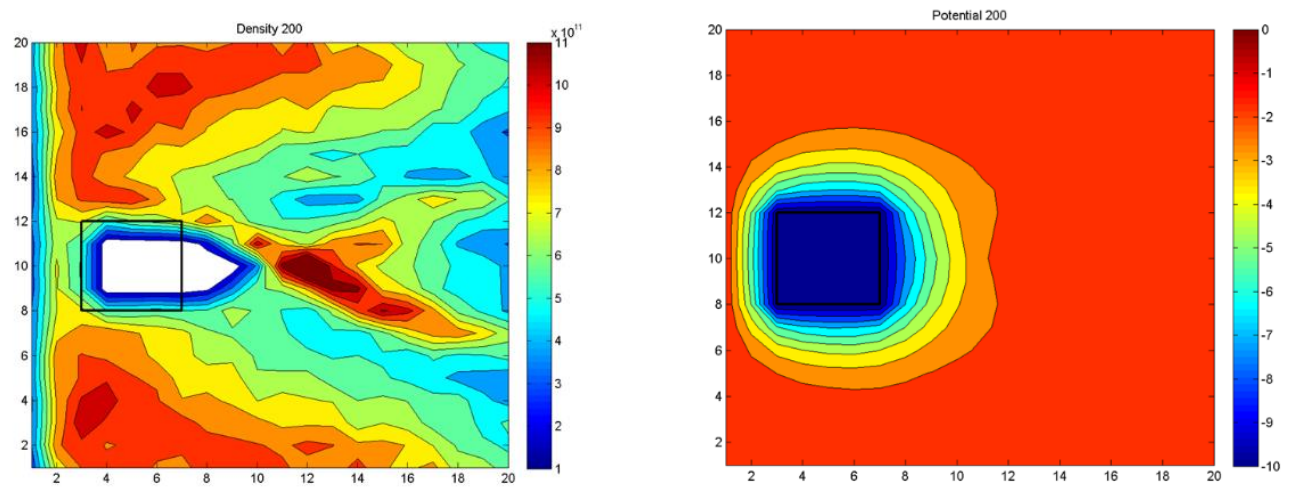

Gambar 2: Variasi injeksi plasma pada kecepatan $10 \mathrm{~km} /$ detik
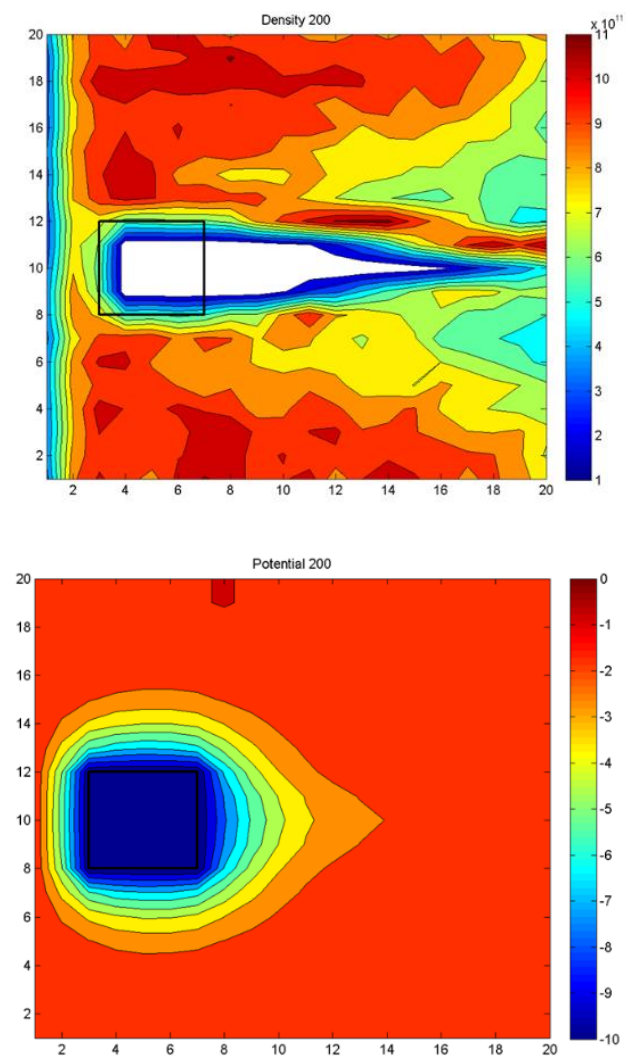

Gambar 3: Variasi injeksi plasma pada kecepatan $20 \mathrm{~km} / \mathrm{detik}$ 

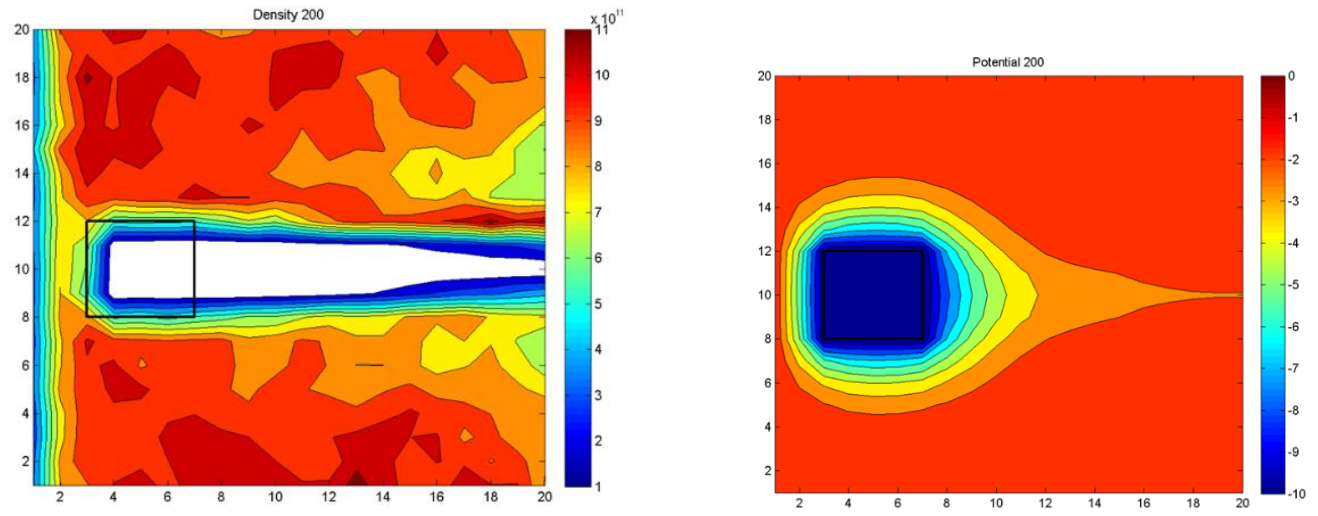

Gambar 4: Variasi injeksi plasma pada kecepatan $30 \mathrm{~km} / \mathrm{detik}$
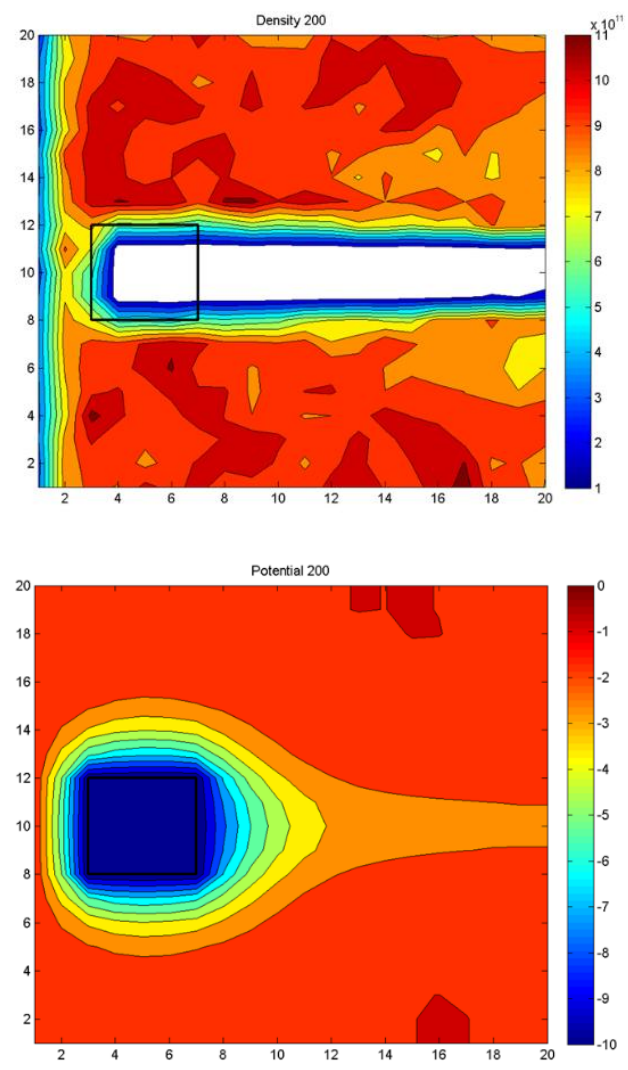

Gambar 5: Variasi injeksi plasma pada kecepatan $40 \mathrm{~km} / \mathrm{detik}$ 

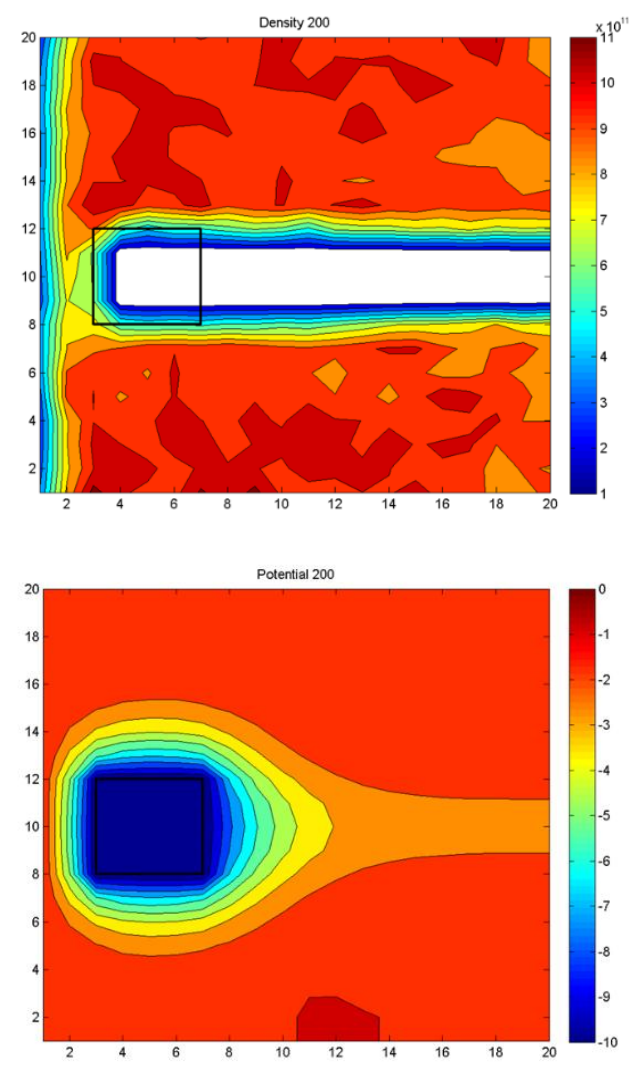

Gambar 6: Variasi injeksi plasma pada kecepatan $50 \mathrm{~km} / \mathrm{detik}$

Pengaruh variasi kecepatan injeksi plasma pada distribusi kerapatan muatan yaitu: jika kecepatan injeksinya diperbesar maka akan terdapat ruang kosong berupa warna putih dibelakang daerah potensial penghalang. Pada saat kecepatan injeksi plasma masih 5 $\mathrm{km} /$ detik daerah kosong tersebut masih sedikit, bahkan hampir tidak ada. Namun jika diperbesar akan semakin besar, namun konstan ketika mencapai $50 \mathrm{~km} /$ detik. Selain itu jika kecepatan injeksinya diperbesar maka kerapatan muatannya juga semakin besar ini terlihat dengan banyaknya daerah yang berwarna merah. Dimana pada skala, warna merah menunjukkan kerapatan muatan yang besar dan makin kebawah yaitu warna biru menunjukkan kerapatan muatan yang kecil.

Pengaruh variasi kecepatan injeksi plasma pada daerah potensial listrik yaitu: jika kecepatan injeksi plasmanya diperbesar maka dibelakang daerah potensial penghalang terdapat daerah yang berpotensial kecil yang bernilai (-3) yang dipencarkan dibelakang potensial penghalang.

\section{KESIMPULAN}

Variasi kecepatan injeksi pada simulasi plasma yang memiliki potensial penghalang dalam posisi melayang untuk distribusi kerapatan muatan mengakibatkan adanya daerah kosong dibelakang potensial penghalang, dimana jika kecepatan injeksinya diperbesar maka 
daerah kosong tersebut juga semakin besar dan akan konstan ketika mencapai $50 \mathrm{~km} /$ detik. Selain itu juga kerapatan muatannya semakin besar jika kecepatan injeksinya diperbesar. Sedangkan variasi kecepatan injeksi pada simulasi plasma pada daerah potensial listrik mengakibatkan adanya daerah yang berpotensial rendah bernilai (-3) yang dipancarkan dibelakang daerah potensial penghalang.

\section{DAFTAR PUSTAKA}

Henry George Liddell, Robert Scott. (1998). A Greek-English Lexicon, on Perseus

Luo, Q-Z; D'Angelo, N; Merlino, R. L. (1998). Shock formation in a negative ion plasma). Department of Physics and Astronomy.

Sturrock, Peter A. (1994). Plasma Physics: An Introduction to the Theory of Astrophysical, Geophysical \& Laboratory Plasmas. Cambridge University Press.

H. Conrads, M. Schmidt. (2000). Plasma Sources Sci. Technol., 9, pp. 441-454

A. Schutze, J.Y. Jeong, S.E. Babayan, J. Park, G.S. Selwyn, R.F. Hicks. (1998). IEEE Trans. Plasma Sci., 26, p. 1685

C. Tendero, C. Tixier, P. Tristant, J. Desmaison, P. Leprince, Spectrochim. (2006). Ionization and plasma. Acta Part B 61 2. The University of Tennessee, Knoxville Department of Physics and Astronomy. 